\title{
Research Team Studies Resource Agreements
}

The Secretariat of the Canadian Council of Resource Ministers has commenced a thorough review of legislation, programmes and agreements affecting Canada's renewable resources. The review is under the direction of Dr. William E. Haviland, 39, of Montreal, economist with the Canadian Pulp and Paper Association. Dr. Haviland has been granted a leave of absence from the Association to co-ordinate the review activities at Secretariat headquarters. The results of the review are to be submitted to the next plenary session of the Council, in Charlottetown, PEI, this Spring.

Dr. Haviland will be in charge of a research group that will study agreements directly related to renewable resources-water, land, fish, forests and wildlife-as well as agreements bearing on the multi-purpose use of resources, including recreation and regional development. Members of the research team will conduct a series of meetings and interviews with government officials across the country.

The project, which was one of the main recommendations to emerge from the 1961 Resources for Tomorrow Conference, was formally approved by the Council meeting in Montreal last November.

Forestry Aspects Of The Canadian Land Inventory

During the next five years the Federal ARDA Directorate, in co-operation with the Provinces, will be involved in the preparation of a Canadian Land Inventory. The need for such an inventory was stressed by the Resources for Tomorrow Conference and the Senate Special Committee on Land Use; it is an absolute prerequisite if national, provincial, or regional land-use planning is to be conducted on a rational basis.

It is estimated that more than 18 million acres of land in Canada can no longer efficiently support agricultural endeavor. The designation of such lands and the assessment of their capability for alternate uses such as forestry, recreation, and wildlife are prime functions of the inventory.

With special reference to forestry, most of the areas of marginal or submarginal agricultural lands adaptable to wood production are located in eastern Canada. Conversely, in western Canada, there are areas of present forest land which may be better adapted to agricultural use.

Initially, the land inventory will be confined to the present agricultural areas and the fringe areas where agriculture and forestry compete. Soil survey information is available for most of these areas and an agricultural classification system has been adopted. For forestry purposes only minor portions of the country have been covered by forest soil surveys and no forest land classification system has been nationally accepted. It will be a major function of the Federal Department of Forestry, to provide in co-operation with the Provinces, a forest land classification system adaptable to Canadian conditions.

The Canadian Land Inventory will initially provide information for land use planning at the federal and provincial levels. The task of data collection, compilation, analysis and storage is formidable. It is proposed that inventory maps will be published at scales of $1: 50,000$ and $1: 250,000$ and it appears that a computer mapping system, currently under study by ARDA, will greatly facilitate the handling of vast quantities of map data. Statistical information 